\title{
Tertiarius minutulus sp. nov. (Stephanodiscaceae, Bacillariophyta) - a new fossil diatom species from Lake Ohrid
}

\author{
Dušica ZAOVA ${ }^{1, *}$, Aleksandra CVETKOSKA ${ }^{2}$, Danijela MITIC-KOPANJA ${ }^{3}$, \\ Elena JOVANOVSKA ${ }^{4}$, Nadja OGNJANOVA-RUMENOVA ${ }^{5} \&$ Zlatko LEVKOV $^{6}$ \\ ${ }^{1,3,6}$ Institute of Biology, Faculty of Natural Sciences, Arhimedova 3, \\ 1000 Skopje, R. North Macedonia. \\ ${ }^{2}$ Department of Aquatic Ecology, Netherlands Institute of Ecology (NIOO-KNAW), \\ Wageningen, Netherlands. \\ ${ }^{4}$ Institute for Ecology, Evolution and Diversity, Goethe University, Frankfurt, Germany. \\ ${ }^{4}$ Department of Animal Ecology and Systematics, Justus Liebig University Giessen, \\ Giessen, Germany. \\ ${ }^{5}$ Department of Palaeontology, Stratigraphy and Sedimentology, Geological Institute, \\ Bulgarian Academy of Sciences, Sofia, Bulgaria. \\ *Corresponding author: zaovadusica@gmail.com \\ ${ }^{2}$ Email: acvetkoska@yahoo.com \\ ${ }^{3}$ Email: mitickopanja@yahoo.com \\ ${ }^{4}$ Email: jovanovska.eci@gmail.com \\ ${ }^{5}$ Email: ognjanovanadja@gmail.com \\ ${ }^{6}$ Email: zlevkov@pmf.ukim.mk
}

\begin{abstract}
A new fossil diatom species, Tertiarius minutulus sp. nov., is described from a sediment sequence DEEP-5045-1 of Lake Ohrid. The species is characterized by small valves $(3.0-8.0 \mu \mathrm{m})$ with a round shape, a marginal area with radially arranged costae and a central uneven area with scattered areolae. Externally, the alveoli are occluded by cribra perforated by irregularly arranged pores. Internally, the alveoli are simple and areolae are occluded with domed cribra. The marginal fultoportulae are situated on costae close to the valve margin, located on every $5^{\text {th }}$ or $7^{\text {th }}$ thick internal costa. One to three fultoportulae are present on the valve face, each surrounded by two to three satellite pores. One rimoportula is present, positioned on a costa at the valve face/mantle junction. The species is compared with morphologically similar taxa and a detailed differential diagnosis is provided. Tertiarius minutulus sp. nov. is known only as a fossil taxon from Lake Ohrid, with a first occurrence during the early stages of lake basin development.
\end{abstract}

Keywords. Ancient lake, diatom fosil record, new species, taxonomy.

Zaova D., Cvetkoska A., Mitic-Kopanja D., Jovanovska E., Ognjanova-Rumenova N. \& Levkov Z. 2020. Tertiarius minutulus sp. nov. (Stephanodiscaceae, Bacillariophyta) - a new fossil diatom species from Lake Ohrid. European Journal of Taxonomy 670: 1-14. https://doi.org/10.5852/ejt.2020.670 


\section{Introduction}

Lake Ohrid, in the Balkan Peninsula, was formed between 1.9 and $1.3 \mathrm{Ma}$ ago (Wagner et al. 2017). It is the oldest existing European lake and one of the few long-lived lakes around the world (Stanković 1960; Radoman 1985; Dumurdžanov et al. 2004; Albrecht \& Wilke 2008). The lake has accumulated a wealth of sediments throughout its limnological history, which are well constrained in age and hold well-preserved fossils, of which diatoms (Bacillariophyta Karsten) are one of the most diverse and abundant groups of organisms (e.g., Cvetkoska et al. 2016). In order to investigate in greater details the age and origin of Lake Ohrid, and link its geological and biological evolution, a deep drilling project was performed in 2013 within the frames of the ICDP project "Scientific Collaboration on Past Speciation Conditions in Lake Ohrid (SCOPSCO)" (Wagner et al. 2014). A total of $2100 \mathrm{~m}$ of sediment was recovered from four different sites - DEEP, Cerava, Gradište and Peštani. The drilling in the central part of the lake resulted in a recovery of a $569 \mathrm{~m}$ long sediment sequence (DEEP-5045-1). Observations of the diatom communities along the entire length of the core revealed the dominance of planktonic diatoms, mostly belonging to genera of the family Stephanodiscaceae Gleser \& Markarova (Wagner et al. 2014; Cvetkoska et al. 2016; Jovanovska et al. 2016a). The majority of them belongs to Cyclotella (Kützing) Brébisson s. 1., while high abundances of species belonging to Stephanodiscus Ehrenberg and Cribrionella Jovanovska, Cvetkoska, Tofilovska, Ognjanova-Rumenova \& Levkov were also observed in the older parts of the sediment sequence (Wagner et al. 2014, Cvetkoska et al. 2016). In previous studies on this core, several new diatom species such as Cribrionella ohridana Jovanovska, Cvetkoska, Tofilovska, Ognjanova-Rumenova \& Levkov (Jovanovska et al. 2016b), Cyclotella cavitata Tofilovska, Cvetkoska, Jovanovska, Ognjanova-Rumenova \& Levkov and Cyclotella sollevata Tofilovska, Cvetkoska, Jovanovska, Ognjanova-Rumenova \& Levkov (Tofilovska et al. 2016) were described. Further studies on this core resulted in a record of a new species bearing unique morphological features that is described here as Tertiarius minutulus sp. nov. Additional analyses of core samples from Lake Ohrid are of great importance for improving the understanding of the palaeoecology and biochronology of freshwater diatoms, their evolution and the main environmental factors that shaped the diatom community structure over geological time.

\section{Material and methods}

Lake Ohrid (North Macedonia/Albania) is located in a tectonically active graben system in western Macedonia. It is situated in a karstic graben within the Southern Balkan extensional regime (Lindhorst et al. 2010). Earlier studies hypothesized that the age of the lake is between 2 and $10 \mathrm{Ma}$, thus considering it the oldest European lake (Stanković 1960; Radoman 1985). Most recent results from the analyses of the DEEP site sediment sequence suggested that the lake established between 1.9 and 1.3 Ma (Wagner et al. 2017). The lake is $\sim 30 \mathrm{~km}$ long and $15 \mathrm{~km}$ wide, located at an altitude of $693 \mathrm{~m}$ above sea level. The maximum water depth is $289 \mathrm{~m}$, and the total volume of the lake is $55.4 \mathrm{~km}^{3}$ (Lindhorst et al. 2014). The total water inflow can be estimated to $37.9 \mathrm{~m}^{3} \mathrm{~s}^{-1}$, with ca $25 \%$ originating from direct precipitation and $25 \%$ from riverine inflow (Wagner et al. 2010). About 50\% of the total inflow derives from karst aquifers, of which ca $8 \mathrm{~m}^{3} \mathrm{~s}^{-1}$ are supposed to come from Lake Prespa (Wagner et al. 2010). Within the SCOPSCO project in 2013, a total of $2100 \mathrm{~m}$ of sediments was recovered from four different drilling locations (DEEP, Cerava, Gradište and Peštani). In this study, only core samples from the DEEP site were used. This site is located in the central part of the lake at a water depth of $245 \mathrm{~m}$ (Franche et al. 2016), where drilling resulted in a maximum penetration of $569 \mathrm{~m}$ below the lake floor (Wagner et al.2014). The new species, Tertiarius minutulus sp. nov., was observed at $452 \mathrm{~m}$ of the composite sequence that corresponds to an age older than 1.3 Ma (Wagner et al. 2019). The sediment in this part is a mixture of sand, silt and clay (Wagner et al. 2014)

For diatom analyses, ca $0.1 \mathrm{~g}$ of wet sediment was sampled and stored in Sterilin tubes at $4^{\circ} \mathrm{C}$. Samples were prepared using a modification of Renberg's technique (1990). Diatom samples were acid cleaned 
by adding a few drops of cold $10 \% \mathrm{HCl}$ and $35 \% \mathrm{H}_{2} \mathrm{O}_{2}$, and left overnight to remove carbonates. The samples were then boiled ca $30 \mathrm{~min}$ in $37 \% \mathrm{HCl}$ to oxidize the organic matter. Samples were rinsed several times with distilled water and subsequently centrifuged. Diatom slides were prepared using Naphrax ${ }^{\circledR}$. Slides were observed under oil immersion at $1500 \times$ magnification with a Nikon Eclipse 80i microscope, and diatom images were produced using a Nikon Coolpix P6000 camera. For scanning electron microscopy (SEM), the material was prepared by drying clean diatom suspension onto cover slips that were carbon tape attached to the SEM stubs and coated with gold-palladium (Polaron SC7640 sputter coater, Quorum Technologies, Ashford, UK). SEM observations were performed using a Cambridge S4 Stereoscan at $10 \mathrm{kV}$ (Cambridge Instruments Ltd, Cambridge, UK) at the Friedrich Hustedt Study Centre for Diatoms (BM), Bremerhaven, Germany.

The holotype slide is designated and deposited at the Macedonian National Diatom Collection (MKNDC), Faculty of Natural Sciences, Skopje, Republic of North Macedonia. An isotype slide is hosted at the Friedrich Hustedt Study Centre for Diatoms (BM), Bremerhaven, Germany. Terminology followes Håkansson \& Khursevich (1997), Houk et al. (2010) and Ognjanova-Rumenova et al. (2015).

\title{
Results
}

\author{
Phylum Bacillariophyta Karsten \\ Class Mediophyceae Medlin \& Kaczmarska \\ Order Stephanodiscales Nikolaev \& Harwood \\ Family Stephanodiscaceae Gleser \& Markarova \\ Genus Tertiarius Håkansson \& Khursevich
}

Tertiarius minutulus sp. nov.

Figs $1-3$

\section{Etymology}

The specific epithet 'minutulus' refers to its small size.

\section{Type material}

\section{Holotype}

REPUBLIC OF NORTH MACEDONIA • Lake Ohrid, core DEEP-5045-1; $41.049167^{\circ} \mathrm{N}, 20.715000^{\circ} \mathrm{E}$; sediment sample from $451.92 \mathrm{~m}$ depth of the composite core; Mar.-Jun. 2013; MKNDC 010093.

\section{Isotype}

REPUBLIC OF NORTH MACEDONIA • 1 spec.; same collection data as for holotype; BM 81918 (slide).

\section{Type locality}

Lake Ohrid core 5045-1, site DEEP, at a depth of $451.92 \mathrm{~m}$ of the composite sequence.

\section{Description}

\section{Light microscope (LM)}

Valves circular, 3.5-8.0 $\mu \mathrm{m}$ in diameter, central area 3.0-6.5 $\mu \mathrm{m}$ in diameter (Fig. 1). Valve face uneven with two parts of distinctly different morphology. Marginal area with short, radiating striae exceeding $1 / 8-1 / 4$ of valve diameter, with ca $24-30$ striae in $10 \mu \mathrm{m}$. Central area uneven and colliculate with scattered central areolae that are not radially arranged. Frustules rectangular in connective view. 
SEM external view (Fig. 2)

Valve face uneven and colliculate (Fig. 2A-C), with small granules in central area (Fig. 2D-E). Areolae present in central area with simple round openings. Marginal striae short, occluded by cribra, perforated with pores of variable size. Line of bigger pores bordering each costa (Fig. 2D-E). Marginal fultoportulae situated on costae, close to margin edge (Fig. $2 \mathrm{~A}-\mathrm{B}$ ), situated on every $6^{\text {th }}-7^{\text {th }}$ costa. Externally marginal fultoportulae with simple, slightly elevated and round opening (Fig. 2C, E). One to three valve face fultoportulae present, with external small openings, round (Fig. 2A-B). Single solid ligulate girdle band present (Fig. 2A).

SEM internal view (Fig. 3)

Internal valve face flat with several central areolae occluded with domed cribra (arrow in Fig. 3B). Marginal areolae loculate, crossed with inwardly raised circumferential silica trabeculae (arrowhead in Fig. 3B), while central areolae occluded with domed cribra (Fig. 3B-C). Costae strongly thickened, ca 30 in $10 \mu \mathrm{m}$ (Fig. 3A, E-F). Marginal fultoportulae with short tube located on short and narrow costae (Fig. 3A). Each marginal fultoportula with two satellite pores in lateral position (arrow in Fig. 3A). One to three valve face fultoportulae present. Valve face fultoportulae with short central tube surrounded with 2-3 satellite pores (arrow in Fig. 3E). One rimoportula present, located at valve face/mantle junction in the middle of costa (arrow in Fig. 3F) or on its side (arrow in Fig 3D). Rimoportula consists of short and narrow labium with oblique slit (Fig. 3D-F).

\section{Distribution}

Freshwater fossil species observed only at its type locality, Lake Ohrid.

\section{Differential diagnosis}

The main differential features of T. minutulus sp. nov. that can be observed in LM are its small valve size (diameter $=3.5-8.0 \mu \mathrm{m})$ and the presence of central scattered areolae that are not radially arranged. Tertiarius pygmaeus (Pantocsek) Håkansson \& Khursevich (1997: 22) is characterized by a valve diameter ranging from 8.0-16.0 $\mu \mathrm{m}$, and occasionally the areolae are not arranged in radial striae (e.g., Pantocsek 1892: figs 2: 22, 4: 59; Houk et al. 2010: fig. 296: 1, 4). Important differences between T. minutulus sp. nov. and T. pygmaeus can be observed with SEM. The marginal striae in T. pygmaeus do not have a complex alveolar structure and are composed of regular rows of fine pori. Externally, distinct

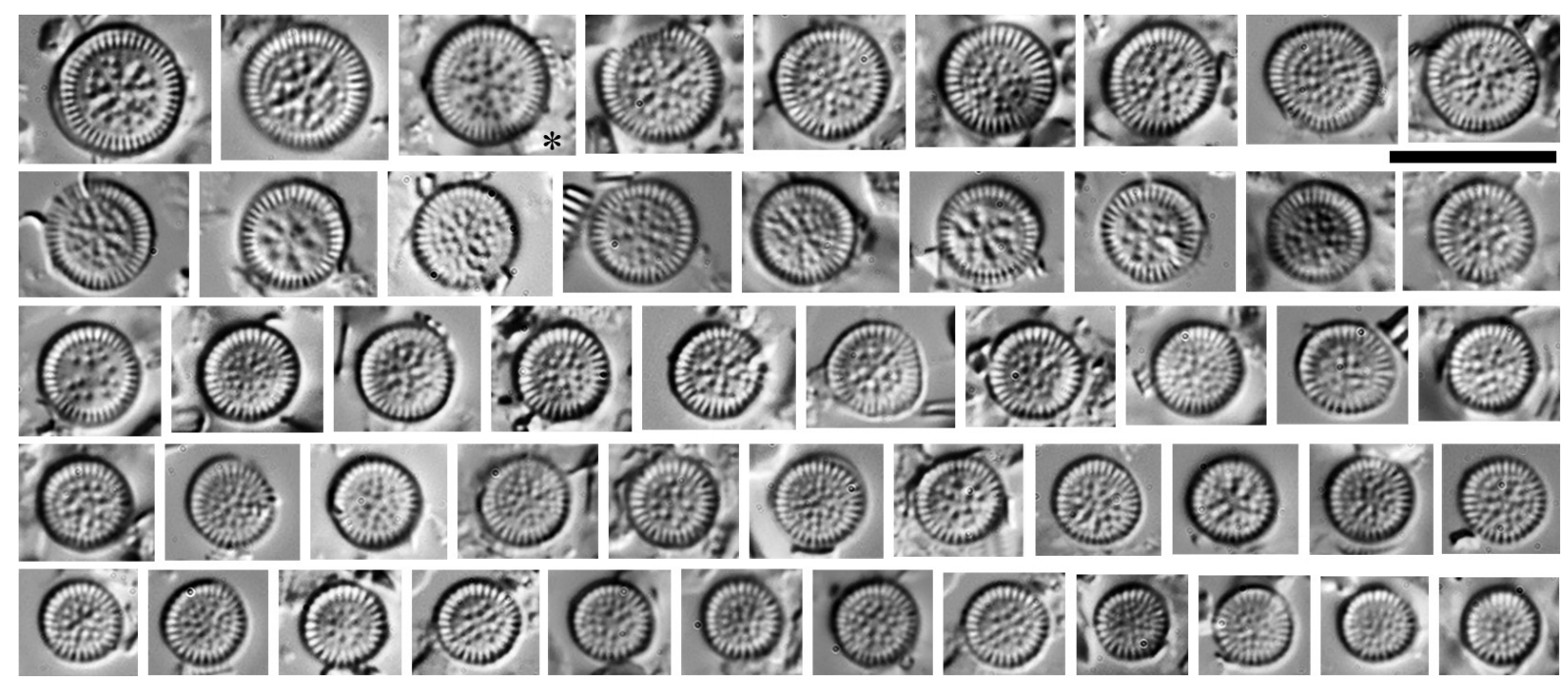

Fig. 1. Tertiarius minutulus sp. nov., LM valve views, Lake Ohrid, North Macedonia. The asterisk indicates the holotype. Scale bar $=10 \mu \mathrm{m}$. 


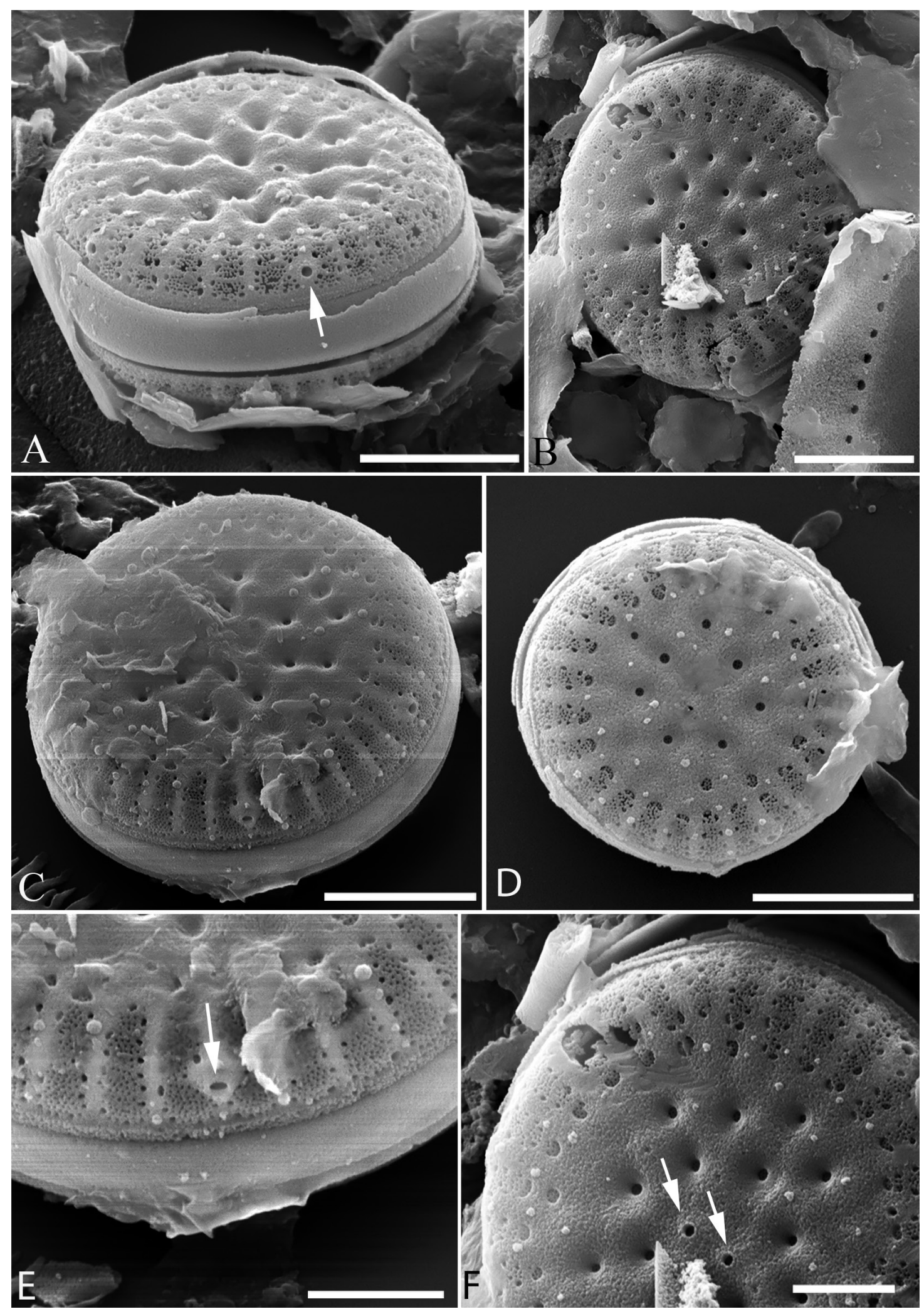

Fig. 2. Tertiarius minutulus sp. nov., SEM external valve views. A. Valve view showing the marginal openings of the fultoportulae (see white arrow). B-D. View of the whole frustule. E. Close view of marginal openings of the fultoportula (see white arrow). F. Close view of the external openings of the valve face fultoportulae (see white arrows). Scale bars: $\mathrm{A}-\mathrm{D}=2.0 \mu \mathrm{m} ; \mathrm{E}-\mathrm{F}=1.0 \mu \mathrm{m}$. 

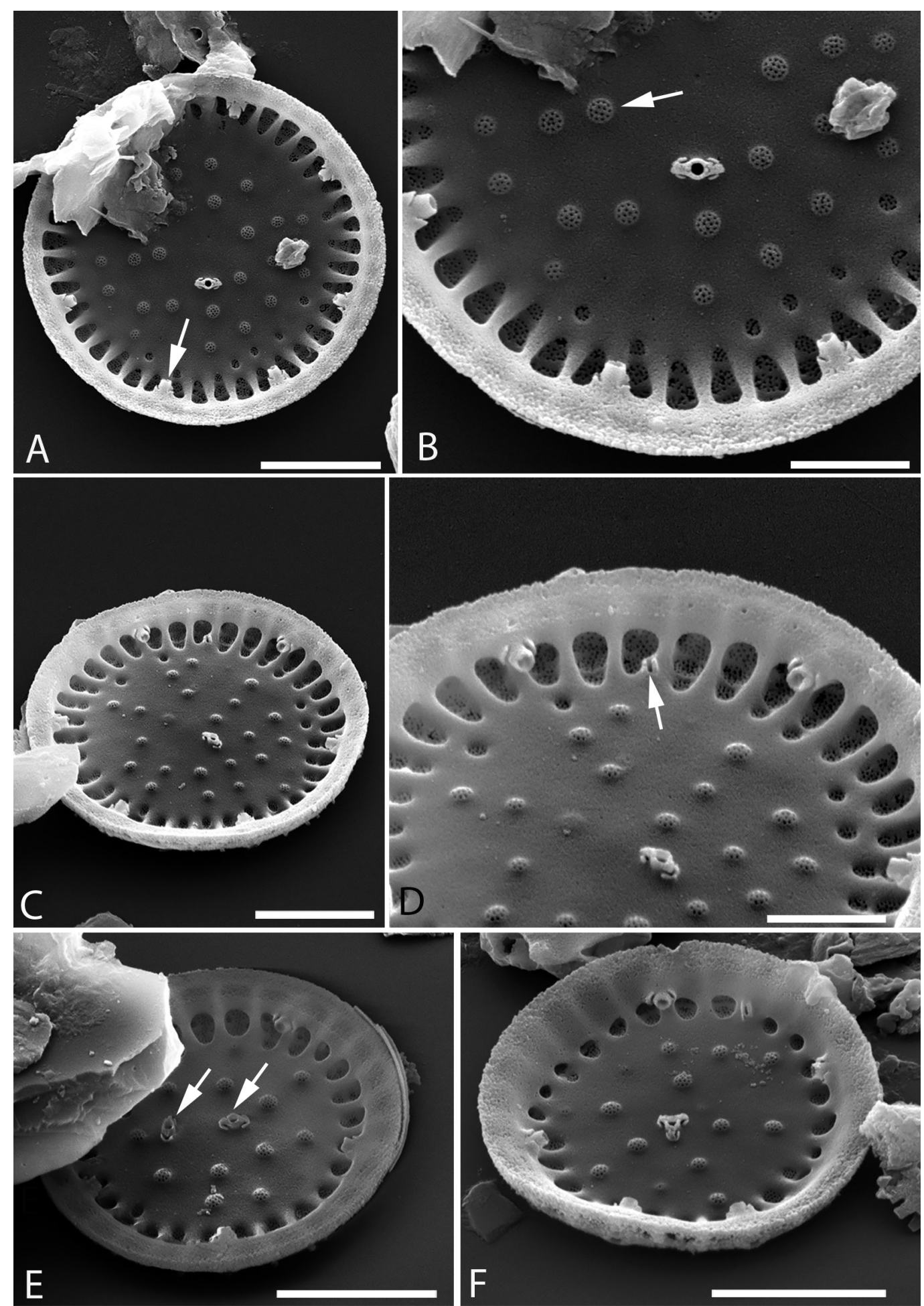

Fig. 3. Tertiarius minutulus sp. nov., SEM internal valve views. A. View of the whole frustule and the marginal fultoportulae surrounded by two satellite pores, cowlings absent (see white arrow). B. Close view of marginal areolae with circumferential silica trabeculae and central areolae occluded by domed cribra (see white arrow). C. View of the whole frustule. D. Close view of rimoportula (see white arrow) located on costa at junction between valve face/mantle. E. Internal valve view showing the central fultoportulae with short central tube surrounded with 2-3 satellite pores (see white arrows). F. Valve view. Scale bars: A, C, E-F $=2.0 \mu \mathrm{m} ; \mathrm{B}, \mathrm{D}=1.0 \mu \mathrm{m}$. 
spines are present on every costa. Internally, the alveolus is round and small in T. pygmaeus whereas it is larger and more elongated in T. minutulus sp. nov. In T. pygmaeus, the marginal fultoportulae are present on each costa, the number of valve face fultoportulae is one to seven scattered in the central area, and the rimoportula is situated inside of the alvelolar opening on a side of costa. Additionally, the costae are much thicker and with a lower density $(8-10$ in $10 \mu \mathrm{m})$ in T. pygmaeus than in T. minutulus sp. nov.

Another species with small-sized valves is T. mariovensis Ognjanova-Rumenova, Jovanovska, Cvetkoska \& Levkov (diameter 4.0-19.0 $\mu \mathrm{m}$ ), recently described from a diatomite near the village Manastir, Mariovo Neogene Basin, Republic of North Macedonia (Ognjanova-Rumenova et al. 2015: 56, figs 36-105). This species was also observed in several sediment samples from Lake Ohrid DEEP5045-1 core. However, both species can easily be differentiated by the structure of the central area. In T. mariovensis, the areolae in the central area form radially arranged striae. The number of valve face fultoportulae in T. mariovensis is higher (2-9) and the tube of the central fultoportula is always surrounded by three satellite pores. Additionally, the marginal fultoportulae are positioned on every costa, while the rimoportula is located inside and in the middle of the alveolus, but not connected to a costa as in T. minutulus sp. nov. Another small-sized species, Tertiarius distinctus Khursevich \& Kociolek (2002: 333, figs 1-5, 12-22), has a comparable valve size as T. minutulus sp. nov. (diameter $4.5-14.0 \mu \mathrm{m}$ ), but coarser areolae arranged in short or long radial striae composed of large areolae, while the marginal striae are composed of 4-6 rows of small pori. Marginal fultoportulae are present on every costa, while in the central area there are 1-5 valve face fultoportulae. The rimoportula is located near the base of a costa within the alveolus. Differences between $T$. distinctus and T. minutulus sp. nov. can be noticed in the structure of the marginal and central striae, the number of valve face and marginal fultoportulae, and the position of the rimoportula. Smaller specimens of $T$. indigenus Khursevich \& Kociolek (2002: 336, figs 6-11, 23-32) have a valve size comparable to T. minutulus sp. nov. (diameter 5.0-27.5 $\mu \mathrm{m}$ ). However, differences between these two species can be noticed in the striae structure (longer marginal striae composed of 4-5 regular rows or pori), central area (colliculate central area with 3-5 large areolae and several 'bumps'), presence of fultoportulae on each costa and one to several rimportulae located on thinner costae within the alveolar chamber.

Tertiarius baicalensis Khursevich \& Fedenya (in Khursevich et al. 2003: 306, figs 1: 1, 2, 4, 5, 14) is characterized by circular valves with flat face and diameter of $6.4-16.6 \mu \mathrm{m}$, three to 17 valve face fultoportulae arranged in radial rows and one to four sessile rimoportulae located in the submarginal zone of the valve face. Differences between T. minutulus sp. nov. and T. baicalensis can be noticed in the ornamentation of the central area (areolae organized in radial striae in T. baicalensis), number and position of valve face fultoportulae, number of satellite pores on marginal fultoportulae (three satellite pores in T. baicalensis), and position of rimoportula(e) that are located in the submarginal zone of the valve face (not connected with costa or within the alveolar chamber).

Another small-celled species, Cribrionella ohridana, was recently described from the same core from Lake Ohrid (Jovanovska et al. 2016b). Both species share several characters such as small size (2.0$7.5 \mu \mathrm{m}$ in diameter), the presence of areolae in the central area and a single rimoportula situated on a costa, marginal fultoportulae located on each $4^{\text {th }}-5^{\text {th }}$ costa surrounded by two satellite pores and the presence of inwardly raised circumferential silica trabeculae. However, differences between these two species can be noticed in the absence of valve face fultoportula in C. ohridana and areolae internally not occluded with domed cribra as in T. minutulus sp. nov.

One of the dominant and very frequent species in fossil diatom assemblages of Lake Ohrid is Cyclotella minuscula (Jurilj) Cvetkoska. Cyclotella minuscula was recently transferred to Lindavia (Schütt) De Toni \& Forti as L. minuscula (Jurilj) Nakov, Guillory, Julius, Theriot \& Alverson (Nakov et al. 2015) and later to the genus Pantocsekiella Kiss \& Ács as P. minuscula (Jurilj) Kiss \& Ács (Ács et al. 2016). 


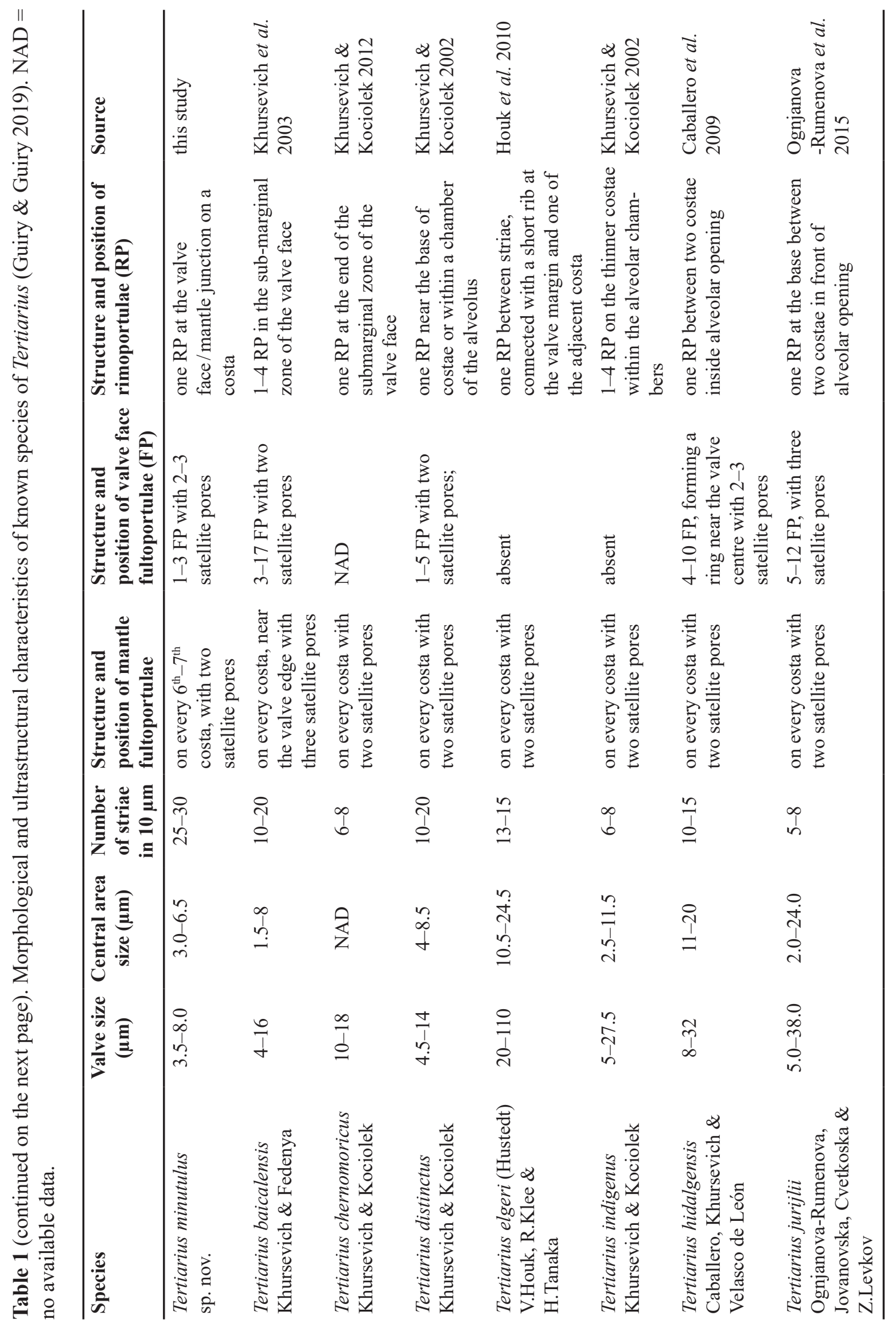


ZAOVA D. et al., Tertiarius minutulus, a new fossil diatom from Lake Ohrid

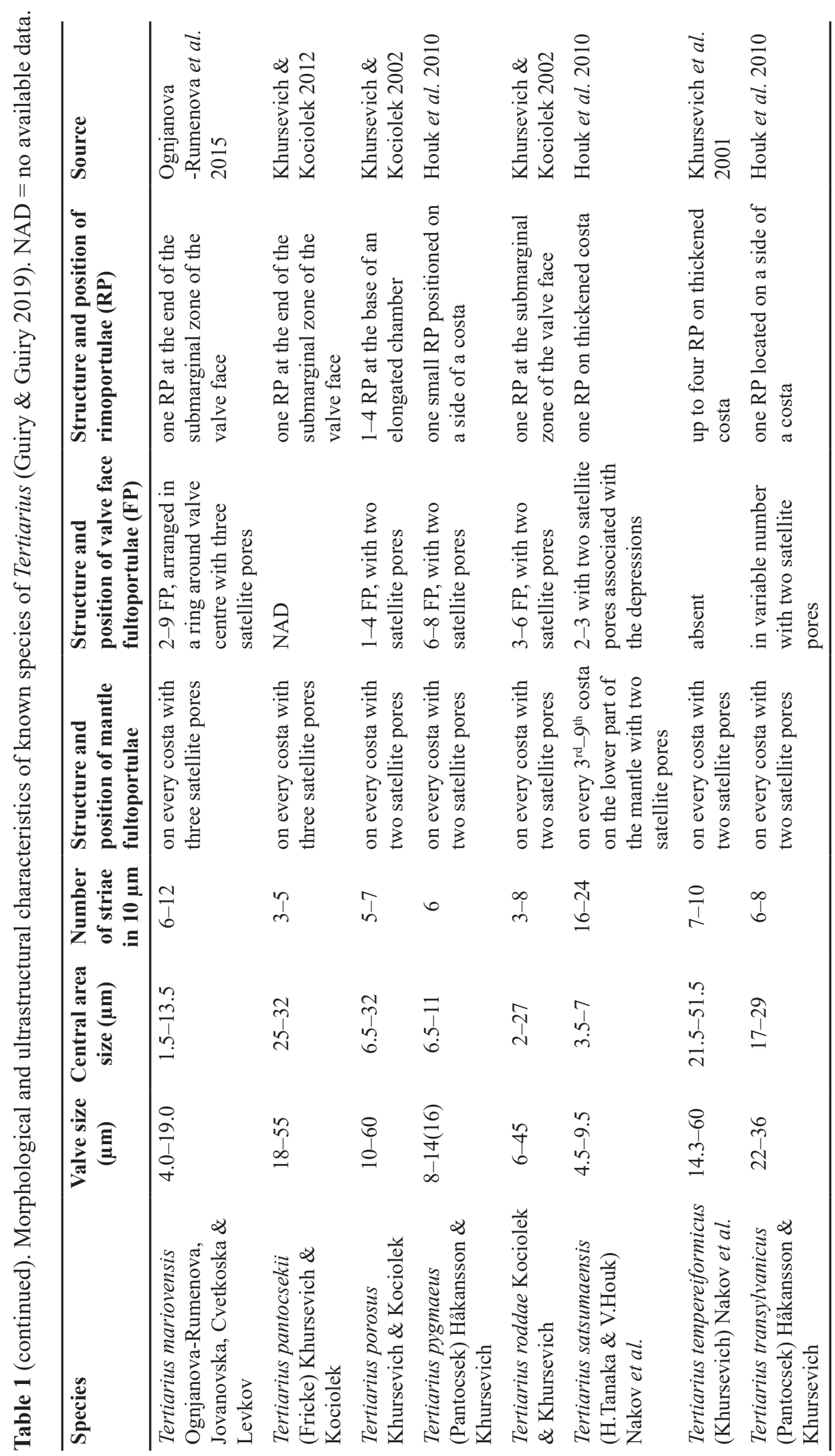


Both species, Tertiarius minutulus sp. nov. and Cyclotella minuscula, have a similar valve size (diameter 3-7 $\mu \mathrm{m}$ in C. minuscula), a colliculate central area, a small marginal zone, a single valve face central fultoportula, a marginal fultoportula with two satellite pores located on each $4^{\text {th }}-10^{\text {th }}$ costa and a single rimoportula positioned at a rib, beneath the ring of marginal fultoportulae. Difference between these two species can be observed only in a presence/absence of areolae in the central area: in C. minuscula areolae are absent, while in $T$. minutulus sp. nov. they are present.

\section{Discussion}

Earlier studies have described 17 taxa (16 species and one variety) which belong to the genus Tertiarius (Guiry \& Guiry 2019), Table 1. The initial description of the genus Tertiarius is based on sediment samples of Miocene and Pliocene age from Köpecz (Transylvania, Romania). Furthermore, new species of Tertiarius have been described from deposits in the western USA (Khursevich \& Kociolek 2002), Pliocene sediments from Mexico (Caballero et al. 2009) and Middle Pliocene sediments from Lake Baikal in Asia (Khursevich et al. 2003). In addition, two species from this genus, viz., T. jurijlii Ognjanova-Rumenova, Jovanovska, Cvetkoska \& Z.Levkov and T. mariovensis, are described from sediments of Pliocene age from Mariovo Basin, North Macedonia (Ognjanova-Rumenova et al. 2015). The presence of Tertiarius mariovensis is also recorded from sediments of Lake Ohrid, at ca $630 \mathrm{ka}$ (Francke et al. 2016). According to Khursevich \& Kociolek (2012), the biostratigraphic range of species from the genus Tertiarius in the Northern Hemisphere extends into the Miocene to Pliocene periods. Interestingly, both T. mariovensis and T. minutulus sp. nov. have been observed in Middle Pleistocene up to Quaternary sediments. These two recent records of Tertiarius probably represent the latest occurrence of the genus in freshwater habitats, again supporting the notion of Lake Ohrid being refugium for many species throughout its existence.

SEM observations indicate that $T$. minutulus sp. nov. shares characteristics with the genus Lindavia (Schütt) De Toni \& Forti (= Handmania M.Peragallo = Puncticulata Håkansson). The genus Tertiarius is considered as fossil with a biostratigraphic range from Miocene to Pliocene, while Lindavia (= Handmannia M.Peragallo) has a longer range from Middle Eocene to present. Tertiarius is characterized by laterally positioned rimoportula on a fultoportula-bearing costa, while in Lindavia, the rimoportula is located on the valve face (Nakov et al. 2015). In the latter study, the authors proposed a broad concept of the genus Lindavia, but Ács et al. (2016) narrowed the concept with a description of the newly erected genus Pantocsekiella Kiss \& Ács (in Ács et al. 2016: 62). Both Lindavia and Pantocsekiella have the rimoportula situated on the valve face. However, the position of the rimoportula can be variable (Houk et al. 2010, Cvetkoska et al. 2014). Similarly, in Tertiarius, the position of the rimoportula is variable: in some species it is located in the alveolus (e.g., T. mariovensis), on the side of costa (e.g., T. pygmaeus), or in the marginal zone (T. baicalensis). In most species of Lindavia, the rimoportula is located on the valve face, but in L. thienemannii (Jurilj) Nakov, Guillory, Julius, Theriot \& Alverson, it is associated with a costa and situated near the valve face/mantle junction (Levkov unpubl. data). Another important feature of T. minutulus sp. nov. is the arrangement of marginal fultoportulae (on every $6^{\text {th }}-7^{\text {th }}$ costa). In all species of Tertiarius so far observed with SEM, marginal fultoportulae are located on every costa whereas it is on every $3^{\text {rd }}-7^{\text {th }}$ costa in species of Lindavia (Houk et al. 2010).

In general, species of Tertiarius and Lindavia can be differentiated mainly by the position of the rimoportula. Tertiarius minutulus sp. nov. shares the features of both genera and might be placed in any of these two genera. Based on the number and position of fultoportulae, T. minutulus sp. nov. can be related to Lindavia, but based on the position of rimoportula it is closer to Tertiarius. Since the occurrence of this fossil species is in relatively deeper geological time, molecular analyses that would uncover its phylogenetic status are yet rather impossible (see for example ancient DNA limitation in Wilke et al. 2016). 
Khursevich \& Stachura-Suchoples (2008) consider the genus Tertiarius to be closely related to the genus Pliocaenicus F.E.Round \& Håkansson (Round \& Håkansson 1992: 116) based on the position of the internal domed cribra on valve face areolae, the presence of alveolae mainly on the valve mantle and the external opening of the rimoportula lacking tubuli. The main features that distinguish these two genera are the valve undulation, absence of externally domed interfascicles, different type structure of the rimoportula (i.e., fan-shaped, sessile or raised) and different location of rimoportula - on the valve surface in Pliocaenicus and on the valve mantle in Tertiarius. Based on these differential features, T. minutulus sp. nov. can be distinguished from P. hercynicus F.E.Round \& Håkansson and P. undulatus F.E.Round \& Håkansson (Round \& Håkansson 1992).

Tofilovska et al. (2016: 230) discussed in detail the validity of the transfer of Cyclotella minuscula to Lindavia, pointing out the variability of a main synapomorphic character, the position of the rimoportula, that is quite variable in this species (see also Levkov et al. 2007 and Cvetkoska et al. 2014). Similarly, as in Cribrionella ohridana and T. minutulus sp. nov., the rimoportula in Cyclotella minuscula is located at the base of costa. Having in mind that the position of rimoportula should be considered as a main synapomorphic character, then these three species (Cyclotella minuscula, Cribrionella ohridana and Teriarius minutulus sp. nov.) might represent a natural group and could be placed in the same genus. This raises another important question about the stability of characters considered as synapomorphic for any particular genus. As was pointed out, the position and location of rimoportula, the presence of valve face fultoportulae, the number of satellite pores on the fultoportulae, the presence of central lamina, etc. are variable characters within each genus. In such case, the only possible and obviously accepted solution in diatom systematic is to use a combination of characters that is unique for each genus. However, this approach can result in the future in separation and description of new cyclotelloid genera, based on already noted and differentiated morphological groups by Khursevich \& Kociolek (2012). There is a general consensus that the number of diatom genera is underestimated, but the main task is to find appropriate and stable morphological characters that are synapomorphic for all members of the genus. There are several recent studies that resulted in synonymization of newly described genera (e.g., Neofragilaria D.M.Williams \& F.E.Round, Synedrella Round \& N.I.Maidana, Lacunicula LangeBertalot, Cavacini, Tagliaventi \& Alfinito, etc.), since the characters used for their separation are present in other genera. However, whether this is the case with Tertiarius and Lindavia and whether both genera represent a single genus, remains an open question.

It seems that in the older species of Tertiarius, the rimoportula is located near the valve margin (within the alveolus or connected with the costa) while in T. minutulus sp. nov., it is located on the costa. In contemporary species of Lindavia, the rimoportula is located on the valve face distantly from the costa. It might be hypothesized that during the evolution, the rimoportula moved from the valve margin to the valve face. A similar pattern can be noticed in Cyclotella vs Pantocskiella, where in Cyclotella s. str. the rimoportula is located on the valve mantle while in Pantocsekiella it is on the valve face. In some fossil species of Cyclotella (e.g., Cyclotella iris Brun \& Héribaud-Joseph) the rimoportula is located on the transition of valve the mante to the valve face (e.g., Houk et al. 2010: fig.s 183: 5). However, additional SEM observations especially on fossil species of Lindavia and Pantocsekiella are necessary to obtain a precise answer.

\section{Acknowledgements}

The samples were obtained thanks to the ICDP deep drilling campaign in Lake Ohrid, financed by the research project Scientific Collaboration on Past Speciation Conditions in Lake Ohrid (SCOPSCO), the German Ministry of Higher Education and Research, the German Research Foundation, the University of Cologne, the British Geological Survey, the INGV and CNR (both Italy), and the governments of the Republic of North Macedonia and the Republic of Albania. This study was supported by the Alexander von Humboldt foundation by providing financial support for ZL for SEM analyses at the Hustedt Diatom Study Centre, Bremerhaven, Germany. 


\section{References}

Ács E., Ari E., Duleba M., Dressler M., Genkal S.I., Jakó E., Rimet F., Ector L. \& Kiss K.T. 2016. Pantocsekiella, a new centric diatom genus based on morphological and genetic studies. Fottea 16 (1): 56-78. https://doi.org/10.5507/fot.2015.028

Albrecht C. \& Wilke T. 2008. Ancient Lake Ohrid: biodiversity and evolution. Hydrobiologia 615: 103-140. https://doi.org/10.1007/s10750-008-9558-y

Caballero M., Khursevich G. \& Vazquez De León P. 2009. Tertiarius hidalgensis, a new diatom species from Neogene deposits in central México. Diatom Research 24: 23-33.

https://doi.org/10.1080/0269249X.2009.9705781

Cvetkoska A., Hamilton P.B., Ognjanova-Rumenova N. \& Levkov Z. 2014. Observations of the genus Cyclotella (Kützing) Brébisson in ancient lakes Ohrid and Prespa and a description of two new species C. paraocellata sp. nov. and C. prespanensis sp. nov. Nova Hedwigia 98 (3-4): 313-340. https://doi.org/10.1127/0029-5035/2014/0154

Cvetkoska A., Jovanovska E., Francke A., Tofilovska S., Vogel H., Levkov Z., Donders T., Wagner B. \& Wagner-Cremer F. 2016. Ecosystem regimes and responses in a coupled ancient lake system from MIS 5b to present: The diatom record of lakes Ohrid and Prespa. Biogeosciences 13: 3147-3162. https://doi.org/10.5194/bg-13-3147-2016

Dumurdžanov N., Serafimovski T. \& Burchfiel B.C. 2004. Evolution of the Neogene-Pleistocene Basins of Macedonia. Geological Society of America, Digital Map and Chart Series 1: 1-20.

Francke A., Wagner B., Just J., Leicher N., Gromig R., Baumgarten H., Vogel H., Lacey J.H., Sadori L., Wonik T., Leng M.J., Zanchetta G., Sulpizio R. \& Giaccio B. 2016. Sedimentological processes and environmental variability at Lake Ohrid (Macedonia, Albania) between $637 \mathrm{ka}$ and the present. Biogeosciences 13 (4):1179-1196. https://doi.org/10.5194/bg-13-1179-2016

Guiry M.D. \& Guiry G.M. 2019. AlgaeBase. World-wide electronic publication, National University of Ireland, Galway. Available from http://www.algaebase.org [accessed 19 May 2020].

Håkansson H. \& Khursevich G. 1997. Tertiarius gen. nov., a new genus in the Bacillariophyceae, the transfer of some Cyclotelloid species and a comparison to closely related genera. Diatom Research 12: 19-33. https://doi.org/10.1080/0269249x.1997.9705399

Houk V., Klee R. \& Tanaka H. 2010. Atlas of freshwater centric diatoms with a brief key and descriptions, Part III. Stephanodiscaceae A, Cyclotella, Tertiarius, Discostella. Fottea 10 (Supplement): 1-498.

Jovanovska E., Cvetkoska A., Hauffe T., Levkov Z., Wagner B., Sulpizio R., Francke A., Albrecht A. \& Wilke T. 2016a. Differential resilience of ancient sister lakes Ohrid and Prespa to environmental disturbances during the Late Pleistocene. Biogeosciences 13: 1149-1161.

https://doi.org/10.5194/bg-13-1149-2016

Jovanovska E., Cvetkoska A., Tofilovska S., Ognjanova-Rumenova N. \& Levkov Z. 2016b. Description of a new fossil diatom genus, Cribrionella gen. nov. (Bacillariophyta) from Quaternary sediments of Lake Ohrid. Phytotaxa 252: 31-42. https://doi.org/10.11646/phytotaxa.252.1.3

Khursevich G. \& Kociolek J.P. 2002. New Tertiarius (Bacillariophyta: Stephanodiscaceae) species from Western North America. In: John J. (ed.) Proceedings of the $15^{\text {th }}$ International Diatom Symposium: 331-349. Biopress Limited, Bristol.

Khursevich G. \& Kociolek J.P. 2012. A preliminary, worldwide inventory of the extinct, freshwater fossil diatoms from the orders Thalassiosirales, Stephanodiscales, Paraliales, Aulacoseirales, Melosirales, Coscinodiscales, and Biddulphiales. Nova Hedwigia, Beiheft 141: 315-364. 
Khursevich G. \& Stachura-Suchoples K. 2008. The genus Pliocaenicus Round \& Håkansson (Bacillariophyta). Morphology, taxonomy, classification and biogeography. Nova Hedwigia 86: 419444. https://doi.org/10.1127/0029-5035/2008/0086-0419

Khursevich G., Karabanov B.E., Prokopenko A.A., Williams D.F., Kuzmin M.I. \& Fedenya S.A. 2001. Biostratigraphic significance of new fossil species of the diatom genera Stephanodiscus and Cyclotella from Upper Cenozoic deposits of Lake Baikal, Siberia. Micropaleontology 47 (1): 47-71. https://doi.org/10.2113/47.1.47

Khursevich G.K., Fedenya S.A., Kuzmin M.I., Karabanov E.B., Williams D.F. \& Prokopenko A.A. 2003. Morphology of new taxa of the Class Centrophyceae (Bacillariophyta) from the Pliocene and Pleistocene deposits of Lake Baikal (Siberia). Algologia 13 (3): 305-321.

https://doi.org/10.1615/InterJAlgae.v5.i3.70

Levkov Z., Krstic S., Metzeltin D. \& Nakov T. 2007. Diatoms of Lakes Prespa and Ohrid (Macedonia). Iconographia Diatomologica 16, A.R.G. Gantner Verlag K.G, Rugell.

Lindhorst K., Vogel H., Krastel S., Wagner B., Hilgers A., Zander A., Schwenk T., Wessels M. \& Daut G. 2010. Stratigraphic analysis of lake level fluctuations in Lake Ohrid: an integration of high resolution hydro-acoustic data and sediment cores. Biogeosciences 7: 3531-3548.

https://doi.org/10.5194/bg-7-3531-2010

Lindhorst K., Krastel S., Reicherter K., Stipp M., Wagner B. \& Schwenk T. 2014. Sedimentary and tectonic evolution of Lake Ohrid (Macedonia/Albania). Basin Research 27: 84 - 101.

https://doi.org/10.1111/bre.12063

Nakov T., Guillory W.X., Julius M.L., Theriot E.C. \& Alverson A.J. 2015. Towards a phylogenetic classification of species belonging to the diatom genus Cyclotella (Bacillariophyceae): Transfer of species formerly placed in Puncticulata, Handmannia, Pliocaenicus and Cyclotella to the genus Lindavia. Phytotaxa 217 (3): 249-264. https://doi.org/10.11646/phytotaxa.217.3.2

Ognjanova-Rumenova N., Jovanovska E., Cvetkoska A. \& Levkov Z. 2015. Two new Tertiarius (Bacillariophyta, Coscinodiscophyceae) species from Mariovo Neogene Basin, Macedonia. Fottea 15 (1): 51-62. https://doi.org/10.5507/fot.2015.005

Pantocsek J. 1892. Beiträge zur Kenntniss der fossilen Bacillarien Ungarns. III. Süßwasser Bacillarien. Anhang: Analysen 15 neuer Depots von Bulgarien, Japan, Mähren, Rusland und Ungarn. Julius Platzko, Nagytapolcsány.

Radoman P. 1985. Hydrobioidea, a Superfamily Prosobranchia (Gastropoda). II. Origin, Zoogeography, Evolution in the Balkans and Asia Minor. Monographs Vol. 1, Institute of Zoology 1, Beograd.

Renberg I. 1990. A procedure for preparing large sets of diatom slides from sediment cores. Journal of Paleolimnology 4: 87-90. https://doi.org/10.1007/BF00208301

Round F.E. \& Håkansson H. 1992. Cyclotelloid species from a diatomite in the Harz Mountains, Germany, including Pliocaenicus gen. nov. Diatom Research 7 (1): 109-125.

https://doi.org/10.1080/0269249X.1992.9705202

Stanković S. 1960. The Balkan Lake Ohrid and its Living World. Monographiae Biologicae Vol. IX, W. Junk, The Hague.

Tofilovska S., Cvetkoska A., Jovanovska E., Ognjanova-Rumenova N. \& Levkov Z. 2016. Two new fossil Cyclotella (Kützing) Brébisson species from Lake Ohrid, Macedonia/Albania. Fottea 16 (2): 218-233. https://doi.org/10.5507/fot.2016.003 
Wagner B., Vogel H., Zanchetta G. \& Sulpizio R. 2010. Environmental change within the Balkan region during the past ca. $50 \mathrm{ka}$ recorded in the sediments from lakes Prespa and Ohrid. Biogeosciences 7: 3187-3198 https://doi.org/10.5194/bg-7-3187-2010

Wagner B., Wilke T., Krastel S., Zanchetta G., Sulpizio R., Reicherter K., Leng M.J., Grazhdani A., Trajanovski S., Francke A., Lindhorst K., Levkov Z., Cvetkoska A., Reed J.M., Zhang X., Lacey J.H., Wonik T., Baumgarten H. \& Vogel H. 2014. The SCOPSCO drilling project recovers more than 1.2 million years of history from Lake Ohrid. Scientific Drilling 17: 19-29.

https://doi.org/10.5194/sd-17-19-2014

Wagner B., Wilke T., Francke A., Albrecht C., Baumgarten H., Bertini A., Combourieu-Nebout N., Cvetkoska A., D'Addabbo M., Donders H.T., Föller K., Giaccio B., Grazhdani A., Hauffe T., Holtvoeth J., Sebastien Joannin S., Jovanovska E., Just J., Kouli K., Koutsodendris A., Krastel S., Lacey J.H., Leicher N., Leng M.J., Levkov Z., Lindhorst K., Masi A., Mercuri A.M., Nomade S., Nowaczyk N., Panagiotopoulos K., Peyron O., Reed M.J., Regattieri E., Sadori L., Sagnotti L., Stelbrink B., Sulpizio R., Tofilovska S., Torri P., Vogel H., Wagner T., Wagner-Cremer F., Wolff A.G., Wonik T., Zanchetta G. \& Zhang X.S. 2017. The environmental and evolutionary history of Lake Ohrid (FYROM/Albania): interim results from the SCOPSCO deep drilling project. Biogeosciences 14: 2033-2054. https://doi.org/10.5194/bg-14-2033-2017

Wagner B., Vogel H., Francke A., Friedrich T., Donders T., Lacey J.H., Leng M.J., Regattieri E., Sadori L., Wilke T., Zanchetta G., Albrecht C., Bertini A., Combourieu-Nebout N., Cvetkoska A., Giaccio B., Grazhdani G., Hauffe T., Holtvoeth J., Joannin S., Jovanovska E., Just J., Kouli K., Kousis I., Koutsodendris A., Krastel S., Lagos M., Leicher N., Levkov Z., Lindhorst K., Masi A., Melles M., Mercuri A.M., Nomade S., Nowaczyk N., Panagiotopoulos K., Peyron O., Reed J.M., Sagnotti L., Sinopoli G., Stelbrink B., Sulpizio R., Timmermann A., Tofilovska S., Torri P., Wagner-Cremer F., Wonik T. \& Zhang X. 2019. Mediterranean winter rainfall in phase with African monsoons during the past 1.36 million years. Nature 573: 256-260. https://doi.org/10.1038/s41586-019-1529-0

Wilke T., Wagner B., Van Bocxlaer B., Albrecht C., Ariztegui D., Delicado D., Francke A., Harzhauser M., Hauffe T., Holtvoeth J., Just J., Leng M.J., Levkov Z., Penkman K., Sadori L., Skinner A., Stelbrink B., Vogel H., Wesselingh F. \& Wonik T. 2016. Scientific drilling projects in ancient lakes: integrating geological and biological histories. Global and Planetary Change 143: 118-151.

https://doi.org/10.1016/j.gloplacha.2016.05.005

Manuscript received: 8 August 2019

Manuscript accepted: 16 April 2020

Published on: 19 June 2020

Topic editor: Christian de Muizon

Desk editor: Radka Rosenbaumová

Printed versions of all papers are also deposited in the libraries of the institutes that are members of the EJT consortium: Muséum national d'histoire naturelle, Paris, France; Meise Botanic Garden, Belgium; Royal Museum for Central Africa, Tervuren, Belgium; Royal Belgian Institute of Natural Sciences, Brussels, Belgium; Natural History Museum of Denmark, Copenhagen, Denmark; Naturalis Biodiversity Center, Leiden, the Netherlands; Museo Nacional de Ciencias Naturales-CSIC, Madrid, Spain; Real Jardín Botánico de Madrid CSIC, Spain; Zoological Research Museum Alexander Koenig, Bonn, Germany; National Museum, Prague, Czech Republic. 